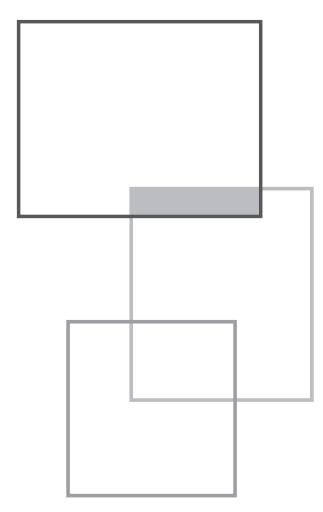

\title{
Références
}

Al-Jadir L., Estier T., Falquet G., Léonard M. (1995) Evolution features of the F2 OODBMS. In: 4th International Conference on Database Systems for Advanced Applications (DASFAA), April 1995, Singapore.

Arni-Bloch N., Ralyté J., Léonard M. (2006) Integrating information systems components: A situation-driven approach, EMMSAD, Conference CAISE*06, June 2006, Luxembourg.

Bodart F., Hennebert A.-M., Leheureux J.-M., Pigneur Y. (1985) Computeraided specification, evaluation, and monitoring of information systems. In: Proceedings of the 6th International Conference on Information Systems (ICIS), 1985, Indianapolis, Indiana, USA.

Burret A. (2015) Tiers-Lieux... et plus si affinités. Editor Fyp Presence.

Burret A. (2017) Étude de la configuration en tiers-lieu : la re-politisation par le service. PhD thesis in Sociology, University of Enlightenment, Lyon, France, 2017.

Drăgoicea M., Léonard M., Ciolofan S.N., Militaru G. (2019) Managing data, information, and technology in cyber physical systems: Public safety as a service and its systems. In: IEEE Access, 2019, vol. 7, pp. 92672-92692.

Estier T., Falquet G., Guyot J., Léonard M. (1991) Six spaces for global information systems design. In: Proc. IFIP Working Conference on The Object-Oriented Approach in Information Systems, October 1991, Quebec City, Canada.

Falquet G., Léonard M., Sindayamaze J. (1993) F2Concept: A database system for managing classes' extensions and intentions. In: 3rd European-Japanese seminar on Information Modelling and Knowledge Bases, June 1993, Budapest. 
Hardin G. (1968) The tragedy of the commons, Rev. Sci. 162(3859), 1243.

Ho D. (2011) Capturing the impact of market dynamics on firm value for service-driven enterprises, The strategic CFO, (U. Hommel, M. Fabich, E. Schellenberg, L. Firnkorn, Eds). Springer, pp. 285-294.

Junet M., Falquet G., Léonard M. (1986) Ecrins/86: An extended entity-relationship data model and its semantic query language. In: Proc. 12th Int. Conf. on Very Large Databases, 1986, Kyoto.

Kant I. (1992) Answering the question what is enlightenment? In: Perpetual peace and other essays on politics, history, and morals. This essay first appeared in the Berlinische Monatsschrift, December, 1784. Translated by Ted Humphrey, 1992, Indianapolis, Hackett Publishing, disponible sur https:// www.stmarys-ca.edu/sites/default/files/attachments/files/Kant--What\%20 Is\%20Enlightenment_.pdf.

Khadraoui A., Arni-Bloch N., Léonard M., Ralyté J. (2005) Laws-Based Ontology for E-Government Information Systems. In: International Conference on Innovations in Information Technology (IIT’05), September 26-28, 2005, Dubaï.

Khadraoui A., Turki S., Aïdonidis C., Léonard M. (2007) Framework for e-government information systems engineering: Describing the organizational layers. In: 2nd IEEE International Conference on Information \& Communication Technologies: From Theory to Application, April 24-28, 2006.

Le Dinh T., Léonard M. (2007) An information system upon information systems for managing and coordinating information system development process. In: 1st International Conference on Research Challenges in Information Science (RCIS), April 2007, Ouarzazate, Morocco.

Khadraoui A., Léonard M., Thi T.T.P., Helfert M. (2009) A framework for compliance of legacy information systems with legal aspect, AIS Trans. Enterp. Syst. 1, 15. 1867-7134, GITO mbH.

Léonard M. (2003) The farandole of fancied conceived and shaped objects in information systems. In: International Workshop on Utility, Usability and Complexity of Emergent Information System, December 2003, Namur, Belgium.

Léonard M., Luong B.T. (1981) Information systems design approach integrating data and transactions. In: IEEE Press, 7th Conference on Very Large Data Bases, 1981, Cannes.

Léonard M., Parchet O. (2016) Information overlap. In: Conference DANTE’99, November 1999, Kyoto.

Ralyté J., Opprecht W., Léonard M. (2016) Reorganizing an enterprise thanks to its information system. In: 18th International Conference on Enterprise Information Systems (ICEIS), April 2016, Rome, Italy. 
Lessig L. (2000) Code is Law: On liberty in cyberspace, 01/01/2000, (Le Code a force de Loi : de la liberté dans le cyber-espace), Harvard Mag., disponible sur http://harvardmagazine.com/2000/01/code-is-law-html.

Maglio P.P., Spohrer J. (2008) Fundamentals of service science, J. Acad. Mark. Sci. 36, 1.

Maglio P.P., Vargo S.L., Caswell N.S., Spohrer J. (2009) The service system is the basic abstraction of service science, Inf. Syst. E-Bus. Manag. 7(4), 395.

Opprecht W., Léonard M. (2011) Co-constructing IS Evolutions with initiatives. In: 13th International Conference on Commerce and Enterprise Computing (CEC), September 2011, Luxembourg.

Osterwalder A., Pigneur Y. (2010) Business model generation: A handbook for visionaries, game changers and challengers. John Wiley \& Sons, Inc.

Ostrom E. (1990) Governing the commons: The evolution of institutions for collective action (political economy of institutions and decisions). Cambridge University Press.

Ralyté J., Léonard M. (2020) "Tiers-Lieu » for services: An exploratory approach to societal progression. In: 10th Conference on Exploring Service Science (IESS), Springer LNBIP 377, February 2020, Porto, Portugal.

Rolland C., Leifert S., Richard C. (1979) Tools for information system dynamics management. In: 5th International Conference on Very Large Data Bases (VLDB), October 1979, Rio de Janeiro, Brazil.

Smith A. (1776) An Inquiry into the nature and causes of the wealth of nations. Publishers: W. Strahan and T. Cadell, London.

Snene M., Léonard M. (2009) Enabling services creation by discovering knowledge overlap. In: First International Symposium on Service Science (ISSS09), February 2009, Leipzig, Germany.

Spohrer J., Kwan S.K. (2009) Service science, management, engineering, and design (SSMED): An emerging discipline - Outline \& references, Int. J. of Inf. Syst. Serv. Sect. 1(3).

Spohrer J., Maglio P.P. (2008) The emergence of service science: Toward systematic service innovations to accelerate co-creation of value, Prod. Oper. Manag. 17(3), 238.

Spohrer J., Maglio P.P. (2009) Service science: Toward a smarter planet, Service engineering (Karwowski \& Salvendy, Eds). Wiley, New York, NY.

Teixeira J.G., Miguéis V., Ferreira M.C., Nóvoa H., e Cunha J.F. (2020) Ten years exploring service science: Looking back to move forward. In: 10th Conference on Exploring Service Science (IESS), Springer LNBIP 377, February 2020, Porto, Portugal. 
Turki S., Léonard M. (2002) Hyperclasses: Towards a new kind of independence of the methods from the schema. In: 4th International Conference on Enterprise Information Systems, ICEIS’2002, Vol. 2, ISBN: 972-98050-67, 2002, Ciudad-Real, Spain.

Turner F. (2006) From counterculture to cyberculture: Stewart Brand, the whole earth network, and the rise of digital utopianism. University of Chicago Press.

Vargo S.L., Akaka M.A. (2009) Service-dominant logic as a foundation for service science: Clarifications, Serv. Sci. 1(1), 32.

Vargo S.L., Lusch R.F. (2004a) Evolving to a new dominant logic for marketing, J. Mark. 68, 1.

Vargo S.L., Lusch R.F. (2004b) The four services marketing myths: Remnants from a manufacturing model, J. Serv. Res., 324.

Vargo S.L., Lusch R.F. (2008a) Service-dominant logic: Continuing the evolution, J. Acad. Mark. Sci. 36, 1.

Vargo S.L., Lusch R.F. (2015) Institutions and axioms: An extension and update of service-dominant logic, J. Acad. Mark. Sci. 44, 5.

Yurchyshyna A. (2015) Towards contributory development by the means of services as common goods. In: 6th Conference on Exploring Service Science (IESS), Springer LNBIP 201, February 2015, Porto, Portugal.

Yurchyshyna A., Opprecht W., Léonard M. (2011) Collaborative decision constructing supported by cross-pollination space. In: Proc. COLLA 2011: The First International Conference on Advanced Collaborative Networks, Systems and Applications, June 2011, Luxembourg.

\section{Pour en savoir plus}

Argyris C. (1996) Actionable knowledge: Design causality in the service of consequential theory, J. Appl. Behav. Sci. 32(4), 390, ISSN 0021-8863 CODEN JABHAP, $114 \mathrm{p}$.

Delobel C. (1978) Normalization and hierarchical dependencies in the relational data model, ACM TODS 3(3), 201.

Spohrer J., Maglio P.P. (2010) Toward a science of service systems: Value and symbols, Handbook of service science (P.P. Maglio, C.A. Kieliszewski, J.C. Spohrer, Eds). Springer, New York.

Vargo S.L., Lusch R.F. (2008) Why "service", J. Acad. Mark. Sci., 25. 